Forum Kritika: Regional Studies on the Chinese Diaspora

in the Philippines

\title{
NAVIGATING CULTURES, FORMING IDENTITIES
}

\author{
Teresita Ang See \\ President, Philippine Association for Chinese Studies \\ Secretary and Treasurer, International Society for the Study of Chinese \\ Overseas \\ Founding President, Kaisa Para sa Kaunlaran \\ Carmelea Ang See \\ Director, Bahay Tsinoy \\ Trainor, Bagong Kulturang Pinoy \\ Consultant, Department of Education
}

\begin{abstract}
This paper recounts the personal history of the Ang Family, focusing especially on three generations of women, starting with the family's matriarch Carmen Davenport Barraca Ang, to her daughter Teresita Ang See, and lastly to Carmalea Yinching Ang See. Each life account brings out stories of bravery, creativity, and perseverance amidst hardships and challenges in a difficult environment. Carmen, for instance, was a Filipina married to a Chinese, who lived in China and then in Binondo. She endeared herself to her husband's Chinese family by learning how to speak Hokkien fluently. Teresita Ang See attended conservative Chinese schools in Binondo but used her experience as a student of political science at the University of the Philippines in helping her late husband Chinben See found in the early 1970s Pagkakaisa Sa Pag-unlad; this was a non-government organization which fought anti-Chinese racism in the country. The story ends with Teresita's children, Carmelea Yinching and Sean Benson, and how they were raised to be comfortable as Filipinos foremost, with the primary identity as Filipino and yet take pride in and promote the duality of their heritage. Through the narratives, the authors aim to give a glimpse of the complexity of identities and identity-formation, shaped as they were by the objective environment and the necessities of the times.
\end{abstract}

\section{Keywords}

Identity, ethnicity, ethnic Chinese, Chinese Filipino, Hokkien, family 


\section{About the Author}

Teresita Ang See is President of the Philippine Association for Chinese Studies, Secretary and Treasurer of the International Society for the Study of Chinese Overseas, and Founding President, Kaisa Para sa Kaunlaran (Unity for Progress). As social activist, educator, cultural worker, and author, she has made outstanding contributions to peace and social cohesion for the past 40 years. She is a community leader and fearless spokesperson of the Tsinoys (Tsinong Pinoy or Chinese Filipino).

Carmelea Ang See is the Director of Bahay Tsinoy, a museum of Chinese in Philippine life and a Vice President for the Chinese-Filipino organization, Kaisa Para sa Kaunlaran. She has a master's degree in Curriculum and Instruction from Lesley University, Cambridge, Massachusetts, USA. As a board member of Bagong Kulturang Pinoy, she is in charge of its training programs: First Steps in Engaged Reading (for beginning readers) and Thinking While Reading (for older readers). 
GROWING UP IN A PREDOMINANTLY FILIPINO NEIGHBORHOOD BEFORE I WAS READY FOR SCHOOL, I never thought that I was different, or what some sociologists call an "essential outsider." The sociologist Daniel Chirot points out that Chinese, especially those of mixed parentage, would employ various methods to assimilate into their surroundings. Many would take on the language and religion of their host society (14).

I spoke Tagalog as my first language, played Filipino games with neighborhood kids, ate primarily Filipino food, know only Filipino vegetables and fruits, and never realized that I was supposed to be ethnically Chinese.

It was when I first went to primary school, the Anglo-Chinese School in Binondo, Manila's Chinatown district, that I felt I was very different from my classmates. I hardly spoke Hokkien, could not understand my teacher, never knew there was a different kind of counting aside from isa, dalawa, tatlo (Filipino words for one, two, three).

My mother was half-Filipino half-American, but was sinicized during her stay in China and she tried to adjust to the parochial ethnocentric Binondo enclave where most of her children were born and where they grew up. My father was a "pure Chinese" who unfortunately died quite young. My colorful ethnic origins shaped my multiracial, multilingual identity. The combination made me unique and the hybridity, I suspect, endowed me with a different intelligence and perception from those of my peers. As the sinologist Leo Suryadinata points out, ethnic Chinese in nations defined in cultural terms (where states seek congruence and unity among different ethnic groups within the country) "are eager to identify themselves with the host communities" (323).

\section{My Mother, Carmen Davenport Barraca Ang}

My mother, Carmen Davenport Barraca Ang, was born on 3 October 1923. Brought up by her American grandparents (the Davenports from Maryland, USA) she barely knew her own mother, Mary Davenport, who died at a young age. Mary had married a Filipino soldier named Filomeno Barraca, who would re-marry after Mary's death. I cannot remember instances when my mother talked about her father, but she often recounted to her grandchildren stories about her very strict stepmother and loving American grandfather, John Davenport, an American soldier, who spoiled her. ${ }^{1}$

Stories of her early childhood were quite colorful, too. She recounted that the first time they went up to Baguio City (the cool summer capital of the Philippines up in the north) with her grandfather was on horseback. It was an agonizing ride up a rough mountain trail. She was then too young to appreciate what she said must have been a breathtaking view. It would be almost fifty years after, in the late eighties, that I would bring her back to Baguio. 
She recounted too how her American grandfather brought her to an officers' club and gave her soda. One time, her grandpa let her taste beer, which she promptly spat out. It must have been from her grandfather that she learned to take coffee as water because when we kids were growing up, we drank coffee for breakfast and for afternoon merienda (snack). No one frowned upon us young children drinking coffee.

During the Japanese occupation, this grandfather, together with other Americans, would be interred in the University of Santo Tomas campus. My mother recounted how she would bring her very young brother along to smuggle some bread for the prisoners without the Japanese knowing.

She was in university studying to be a teacher when the Japanese invaded and occupied the Philippines in 1941. School was suspended during the Japanese occupation but she attended a Japanese class to learn the language. She caught the eye of a Japanese officer because of her innate intelligence and facility in learning Japanese. The officer wanted to send her to Japan to continue her studies. But her father decided that Carmen would marry a Chinese merchant, Jose Ang (洪詩習), who was also courting her, so that she would not "get taken" by the Japanese soldier. She was quite pretty in her old age and must have been prettier when she was young. She had soft brown eyes, a high-bridged nose, and naturally curly hair. She looked quite aristocratic as a young woman.

What Jose did--marrying my mother, a mestizo Filipina--was not uncommon in the Philippines at a time when the Chinese migrants were still mostly males. However, this was contrary to the usual practice in his home province in Houting, Jinjiang (後庁, 晋江), China, whose sons were expected to marry local girls. Apparently, Jose was the only Houting son who married an outsider, and thus Carmen became an object of curiosity in the home village when she first visited.

Minnan men were expected to establish a family and home by taking wives who would guarantee the reproductions of sons, give these sons a proper upbringing, maintain their husbands' household while they were away, and take care of their aging parents. (Chu 47 )

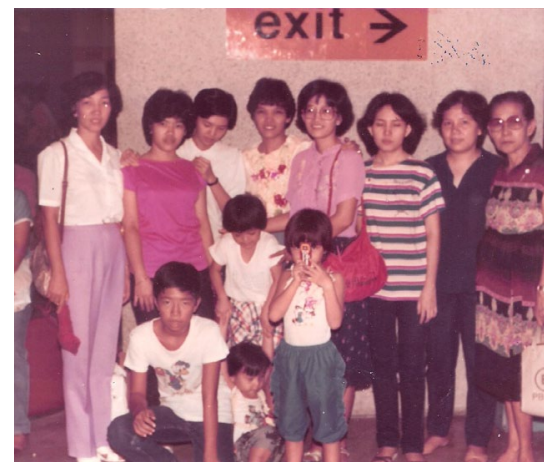

Carmen left university without a degree and did not become a teacher. Instead, she and husband Jose Ang had eleven children in fifteen years.

Fig. 1: At the airport c. 1982. Numbers indicate birth-order of siblings--From left to right: Linda (3), Marilyn (10), Carmen (11), Carmelita (6), Teresita (5), Jocelyn (9), Miracle (wife of \#8), Carmen. Children in front: Fernando Jr., Carmelea, Michelle, and Richelle (littlest one). 
Fernando, the eldest, was born in December 1944, followed by Josefina in March 1946. In 1947 (after the Pacific war), my father brought my mother to his home province in Houting, Jinjiang, China, with the two toddlers in tow. Being the youngest son, my father was his mother's favorite and she demanded to see him and his children. Erlinda, born in August 1947, was an infant when she was left behind in the care of my aunt (my father's eldest sister) while the family visited China. The family stayed in China for a year. When it was time to go back home, my grandmother refused to part with my eldest brother and despite my mother's protest, asked that he be left behind. Fernando remained in China until 1948, when the Communist-Kuomintang civil war escalated. My mother, fearing for her eldest son, rushed to China to bring him back home.

Fernando's first language was therefore Hokkien. His young tongue got used to Hokkien so while growing up as a child in Malabon (around ten kilometers away from Binondo), he could not speak Tagalog well and would be mercilessly teased by the neighbor's kids. He pronounced posporo as popolo (matches), bahay as mahay (house) and so on. He could not pronounce $R$ for the life of him and all $B s$ were pronounced as $M$.

The other sister, Linda, who was left with my older $a$-ko (gumu 姑母; paternal aunt $)^{2}$, was kept by her and not returned to our family when my mother returned to Manila. Although she recognized us as her siblings and our parents as her parents, she also called our $a-k o$ and ko-tiū (guzhang 姑丈,an aunt's husband) father and mother. Linda's first language was also Hokkien but unlike Fernando, who later became more comfortable speaking in Tagalog than Hokkien, Linda had a completely Chinese upbringing. She read only Chinese books and wrote in Chinese and all her children also spoke Hokkien as their first language, with Filipino and English only learned in school.

In my mother's three visits to China, the first one lasting for almost two years and the two other occasions for just a few months, she joined her Chinese sisters-in-law and other children who were being tutored at home (sishu 私塾). ${ }^{3}$ Being innately intelligent, she supposedly learned the Chinese lessons faster than her sisters-inlaw. Often, they would go to her to ask how to read the characters. My mother always had to have her own copy of the lesson because it had pronunciation marks in English. After all, the Chinese girls there were uneducated while my mother was a pre-war second-year college student, taught by the best Thomasite teachers and honed in grammar, conjugation, reading, and writing.

She recounted to her grandchildren that she wrote down in a small notebook the English spelling and meaning of the Hokkien words she was learning. She persevered with this method even if all the words looked the same! One famous story goes that when a sister-in-law asked her to get "te-kho", a Hokkien word meaning "short pants" (duanku 短褲), what she brought her was “te-ko" (chahu 茶 壼), a tea kettle. No matter how confusing, she kept using and filling her notebookthe only language manual she had. 
The ease and speed of learning the language could also have been brought about by the looming threat of not surviving. She often told a story to her grandchildren of being asked by the women in the village if the rumors that all women in the Philippines were taught witchcraft (hiaw tsue khio in Hokkien, hui wushu in Mandarin 會巫术) ${ }^{4}$ were true, to which she answered “yes." This prevented the possible bullying she was expecting.

Part and parcel of the urgency of learning Hokkien is learning about and transacting with the village's and the province's culture. Chris Barker posits that culture is not an external entity that a person grabs:

Rather, they [shared meanings of culture] are the product of signifying practices, most notably those of language. Language constitutes material objects and social practices as meaningful and intelligible, it structures which meanings can or cannot be deployed under determinate circumstances by speaking subjects. To understand culture is to explore how meaning is produced symbolically through the signifying practices of language within material and institutional contexts. (3-4)

When we were growing up, my mother could still memorize the beginning of Sanzi jing (三字經), the Taoist bible, from which they learned their Chinese lessons. Being a born teacher, she taught our house helpers to speak Hokkien and they learned fast and went on to speak it fluently. When relatives from Hong Kong and China came, they would borrow our helpers for a while because of their Hokkienspeaking ability.

We suspect that my mother worked hard to learn the language in order to fit into the strange and hostile environment. She recounted that all the females sat at one table while the males at another. Only the males were given fish or meat during meals and the females would just eat pickled vegetables (jiangcai 酱菜), salted bean curd (douxian 豆咸) and salted beans (douyan 豆腌; tausi in Hokkien). She recounted how she cried because she was not used to eating such sparse meals. Occasionally, the family matriarch, my grandmother, would give her a piece of fish, knowing she was from a foreign land and not used to the food.

The residents of the village in Houting were all surnamed Ang and belonged to the same clan. My mother recounted her experience of taking a bath during winter and giving my older sister (just a toddler then) a bath too. She said all the females in the clan surrounded the outhouse where she was bathing, just to see if she would survive, because they had never encountered anyone taking a bath during winter.

My father's ancestral house was considered one of the biggest and most spacious at that time, with eight rooms in all. The first time I went to my father's village in 2003, they showed me the room where my mother stayed.

When my mother and siblings moved back to Manila from Binondo, they first stayed with my father's siblings. She recounted how badly she was discriminated 
upon. The cleaning of the house was her main responsibility. She said that her sister-in-law would deliberately drop money somewhere to see whether she would pocket it. The sister-in-law did this so often that one time, my mother confronted her, telling her to just leave a bigger amount so she would have enough to leave their house. The "test" stopped after that confrontation. The other confrontation was over her mispronunciation of Chinese words. Their ridicule also stopped when she told off my father's siblings: "Do you see me laughing at you when you always mispronounce Tagalog and know very little of the language? At least, I learned your Chinese but you never took the trouble to learn Tagalog."

\section{My Father, Jose Ang}

My father Jose was a typical spoiled younger son. He was the youngest among four brothers. The eldest died early during the Communist purge, because the Ang family owned property. ${ }^{5}$ The di-peh (erbo 二伯), sa-peh (sanbo 三伯), my father, and his oldest cousin (from the oldest uncle) all came to Manila in the early 1930 . Jose migrated to the Philippines with an elder brother when he was just twelve years old at the height of the civil unrest, warlordism, and skirmishes between the Communist and the Kuomintang armies. My di-peh, sa-peh, and their cousin later opened three stores, all selling flour. My father worked for them as a sales agent and got a monthly salary as well as a commission for working in my uncle's flour store on Elcano Street, Binondo. At the end of the year, after accounts were settled, he would get a share from the profit (pha thiap in Hokkien, huahong in Mandarin 花紅).

But life was not easy when he first came to the Philippines. He said he and his elder brother, who was probably sixteen years old at the time, worked as helpers in a restaurant. They would close the restaurant at 9:0o p.m. and start cleaning up. He went to bed at about 10:0o p.m. while his brother would go to bed at about 11:0o. His brother would then wake up at about 4:00 a.m. to go to market with another worker. My father would wake up at about 5:00 a.m. to start preparing for the opening of the restaurant at about six in the morning. As a result, he said he would always be very sleepy throughout the day. This story brought forth the image and rationale behind the "intsik beho (viejo) tulo laway" ("old Chinese drooling") that Filipinos would tease the Chinese with. The prematurely old Chinaman would always be nodding off with saliva drooling because of perennial lack of sleep.

My sharpest memory of my father was his ability to squat (not sit down) on the floor while holding a magazine and reading. He had stacks of those martial arts magazines, or “bu kiap siaw suat" (wuxia xiaoshuo 武俠小說), as he called them.

On weekends, he would go out to play mahjong with his friends, something that always caused friction between him and my mother, and I remember the quarrels they would have, especially if he gambled away money for our school needs. He was a member of the Chinese mason group, which he called his kiak pay hia ti (jiebai 
xiongdi 結拜兄弟). These sworn brothers of his always helped him out financially, especially if he told them it was for his children's school needs. It was a source of pride for him, and his friends envied him for it, that his children did very well in school and always brought home awards.

During the Japanese occupation, he was a member of the underground Chinese guerrillas. In Malabon when we were growing up, I remembered a story my mother told my elder siblings about how my father threw away all the IOUs he had from the American soldiers, to whom he had secretly delivered rice and supplies. The IOUs were notes of credit from the American soldiers promising to pay in cash at a later date for things procured. My mother was very angry because the money would have been useful, with the kids coming one after another. But my father said that it was the least he could do because it was part of the fight against Japanese aggression and not for monetary rewards.

He appeared to us to be happy-go-lucky, always cheerful despite difficulties in raising one kid after another, always able to cajole friends and relatives to help him out financially. My mother was the one with a regular Monday-to-Saturday job at a cigarette factory and she would still have time to help her children with lessons when she came home.

It was summer, 19 April 1961, when my father died at the age of forty-four. I was barely twelve when my youngest sister was born in August of the same year. How the five-month-old fetus survived with my mother being exposed to so much germs while taking care of my father at the hospital, and how she was born without disability despite being exposed to most of her older siblings, who were stricken with chicken pox, were miracles in our lives. How my mother was able to make ends meet and raise eleven children as a single parent was another miracle.

The "Chinese connection" and my mother's flexible identity with regard to the Chinese side of her environment were probably the greatest factors behind our survival. Although my mother worked, our Chinese relatives still provided her with money to augment our monthly income. But it was her being Filipino that allowed her to find ways to get scholarship grants and additional income support for her children.

\section{My Early Years}

Fig. 2: Sending off Carmelita for her twomonth public service training in Davao (numbers indicate order of siblings). Standing left to right: Carmelita (6), Linda (3), Fernando (1). Seated left to right: Marilyn (10), Carmen, Carmen (11), Jocelyn (9), Teresita (5), Jose, Jr. (4).

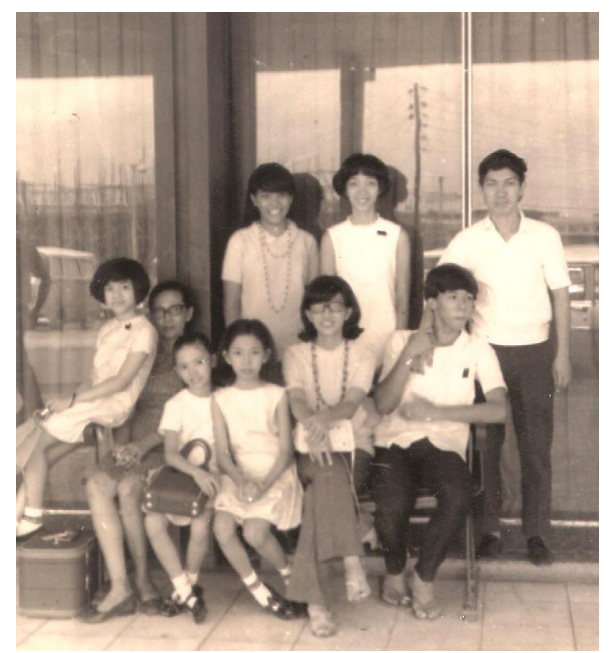


One of my earliest memories of childhood was growing up in Malabon with Filipino kids. There were hardly any Chinese in Malabon then, which was still a very rural town. We lived in a wooden hut with windows all around which brought in strong breezes throughout the day. There were huge mabolo, santol and tamarind trees in the backyard, shading the house. I tagged along with my brothers and sister and helped pick sampaguita buds. We were paid one cent for a full pail of sampaguita flowers that women who sold them then sewed into garlands. I tagged along with my siblings when they swam in the rivers, of course with the strict admonition that I was not to go into the waters. I must have been about four years old then. I remember the very clean river and the big kids picking up talangka (small crabs) and putting them in water dippers to be brought home as food. We picked siniguelas (Spanish plum), camachile (Manila tamarind), and duhat (black plum) everywhere. Our water came from a deep well that occasionally had some butete (tadpoles) in them. Drinking water was placed in a banga (large earthenware jug) that always gave us cool water.

On moonlit nights, I watched my siblings and the neighbor's kids play tumbang preso and patintero $^{6}$ or we would sit down and sing songs. We learned a lot of Filipino folk songs that way. Bahay Kubo (My Nipa Hut, the children's folk song) was part of our growing up and we would go around the neighborhood identifying the vegetables enumerated in the song. My strong identity as a child in a Filipino neighborhood must have formed the early identification with the Filipino part in me (C. See 27-29). Despite being of Chinese descent, I experienced no discomfort in playing with Filipino children and dealing with Filipino neighbors.

Fernando and Josefina were enrolled in the Anglo-Chinese School. They, especially my eldest sister, suffered a lot because they were left with my uncle in Binondo on school days and brought home to Malabon on weekends. Josefina often felt cold and hungry and she would tell us later how she cried every night.

Just before I was old enough for school, we moved to Binondo, Manila, after the chickens my mother was raising in Malabon died in a pestilence. I remember we moved to a small house in the city with Filipino neighbors. My first memory of school was of having to walk for almost an hour to get there. We left the house when it was still dark, and my mother dropped us off at school before she headed to work at the Chelsea Cigarette Factory.

We moved many times, but always around the Binondo area. I remember the houses in Caballeros, San Nicolas, Elcano, Asuncion and back again in Elcano. In particular, I remember the house in San Nicolas. One wall facing the wooden sofa was plastered with our certificates of merit. We were all honor students every year and would bring home the certificates proudly. They were not just from school but also from the Lioc Kui (Ang) Family Association. My eldest brother and sister also won contests in Chinese calligraphy, often referred to in the classroom as mao $b i$ (毛筆), the Mandarin term for the "ink brush made of hair" that we used to write Chinese characters. My eldest sister also won several drawing contests. Her 
drawing of a plate of fruits that won second prize in an inter-school competition looked very realistic, even though they were just done with crayons. One time, she drew a portrait of Abraham Lincoln for fun and even at a young age, I remember it being very lifelike. In high school, her drawing of the animal kingdom from the lowest phylum to the highest earned praises and was passed around by the biology teacher even to my class, which came six years after her.

I could not speak Chinese at all when we went to Binondo, but I was enrolled at the Anglo-Chinese School. The first day of school, my sister drilled into my head how to say "I need to go to the toilet." When I told my teacher I needed to go to the toilet, she answered me but I did not understand her answer and did not know how to tell her that I did not know where to go. I was a greenhorn, a province girl (probinsyana) so scared stiff of my teacher that I peed in class and fell asleep on my desk on the first day of school.

Because the whole school spoke Hokkien as a lingua franca, I learned fast. But I had bad experiences with the Chinese teachers, who were mostly strict disciplinarians. They were probably never drilled in the principles of teaching young children, and this must have been the reason why there was a great resistance among schoolchildren to learning Chinese. In primary grades I was already reading Perry Mason and Emilie Loring. In high school, Agatha Christie and Ian Fleming were the weekly reading fare and my classmates were very happy when I explained to them the stories behind the James Bond movies they watched because they said they could not understand the English dialogue.

I owed my skills in English largely to my mother. Her pre-war second-year college education and her being a born teacher must have rubbed off on us. We were poor but we always had books at home, books that she would buy in second-hand shops on Rizal Avenue. She also made sure that we went to the public library during summers to borrow books. I remember that whenever we visited our cousin's place, we would all head off to read their storybooks, which they didn't even touch. The first set of encyclopedias I saw was at my cousin's house and whenever I visited, I would always browse through them. I told my cousins what a waste it was that the books in the shelves were just for display and not for reading.

Visits to my cousins were my first exposure to class distinction and stereotyping. I thought that my cousins were rich because they were pure Chinese and we were poor because we were half-Filipinos. We also had to learn to adjust our behavior and exercise situational identities to fit in.

Being avid readers must also be the reason why most of us excelled in school. I remember my two most important certificates were won in grades four and six. All grade four students that year (1960) were required to take a government examination. We had to go to school every Saturday afternoon for special review classes to prepare for the exam. As far as I recall, it was the first and only time that grades four and six students were ever given a government exam. The Philippines must have had a surplus budget for education. I did not know how I topped the 
examination in English among all examinees nationwide and I saw my test paper on the Bulletin Board. I didn't understand why it was there until I was given an award during the flag-raising ceremony and the principal announced that I got a grade higher than even the students of the most prestigious high schools like Ateneo de Manila and De La Salle. The grade I got was, I think, 98 percent. The other certificate I treasured was the one I received when I graduated as Valedictorian in grade six with a grade of 97 percent. The certificate stated that it was the highest grade a valedictorian had ever received. I think no one has broken that record as yet.

The duality of heritage never bothered us when we were growing up in a Binondo enclave. Throughout our growing years, it never came up. After the short stay in Malabon, we lived in Binondo. We were brought up as Chinese, we had Chinese neighbors, classmates, and even the helpers learned Chinese. We visited with our Chinese cousins during weekends or during vacations and would spend time also in Alabang (when it was still a province) with my mother's eldest brother, his wife, and only daughter. They lived in a nipa hut then, surrounded by mango trees. Thus, we very much grew up adept at crossing cultural and racial barriers. Some friends of my mother found it strange that we would code-switch from Tagalog to Hokkien and back so smoothly and without conscious effort.

All the Ang children went to the Anglo-Chinese School or to Chiang Kai Shek High School (now College) for primary and secondary education. Both these schools are located in Chinatown. I call them bastions of ultraconservatism and ethnocentrism.

Our neighbors in Binondo were all surprised when they learned that my mother is a Filipina. They often asked her, "How can you speak very good Tagalog without a Chinese accent?" and they would all be surprised and impressed when they learned that she is a Filipina who could speak fluent Hokkien and not a Chinese who spoke fluent Tagalog.

Family ties were strong and we would be forced to visit my father's only sister at Caballeros Street in Binondo or she visited us. She was very strict and stern, tied her hair into a very neat bun. When she asked for warm water, we had to give her a glass at the right temperature or she would get mad and complain that it was either too hot or too cold. She was a typical Chinese disciplinarian, quite authoritarian. My sister Linda, whom she raised, did not go to college immediately after high school because my aunt felt that it would be such a waste for women to go to college since they would be getting married quite soon anyway. That was another part of the Chinese upbringing that was difficult to fathom. It was my mother who helped "negotiate" to have Linda sent to college.

The Chinese neighbors liked my mother despite her being a Filipina, mainly because she could converse with them in Hokkien. Language was the most effective bridge. My mother resented the fact that many of our Chinese neighbors did not treat their house helpers well. My mother would always be the refuge of young 
helpers who incurred the ire of their masters at home. If the complaints were justified, she secretly assisted the house helpers to look for another job.

I remember there would always be subcontracted jobs that we all helped with even as young children. Those were the days before child labor was banned. The work involved odd jobs such as stringing up rubber bands into ten-piece strands and then tying up the ten strands together; wrapping toilet paper rolls; cutting glued pad papers into smaller chunks of pads; and pasting colored strips of paper into notebook spines. My sister would sell knick-knacks in school and my brother preserved fruits on weekends. He had a box filled with preserved mangoes, sancha, and di-kiam and would shout "sancha, suan-a kua, bo chia eh law nua" ("preserved hawthorne, preserved mangoes, if you don't taste them you'll drool with envy"; “shancha, mangguo gan, xian, bu chi hui liuxian” 山查, 芒果干, 咸, 不吃會流涎).

When my father died, our mother was five months pregnant with her last child. It was one of the most difficult times we had. I remember all of us children were down with chicken pox and my father was sick at the hospital. We would cry because of the itchiness, with no one except the older siblings to help us. Then, the younger kids got sick too. I remember only that my oldest brother and I were already well enough to be downstairs when my cousin came to the house and told us that our father had died in the hospital. My mother came home quite late already with a white towel which was wet with her tears.

It was a difficult time, made more difficult because our Chinese relatives imposed on us the strict Chinese funeral traditions. It was 1961 and all Chinese customs were strictly adhered to: food offerings; burning of incense and paper money; and observance of the 7 th day, 49th day, and 1ooth day of death. ${ }^{7}$ It was an older aunt who would prepare the food offering and I remember there was plenty. While we already belonged to the Iglesia ni Cristo (Church of Christ), ${ }^{8}$ we had to adhere to all the Chinese customs. We were in mourning clothes for three years. ${ }^{9}$

My mother worked to make ends meet. When my father died, his family did not provide my mother with the regular salary and commission given to my father when he was alive. Instead, they gave my mother a monthly income support representing my father's share of the business. I was probably in high school already when my uncles and cousin decided to keep the business to themselves and gave a small token amount to my mother for what remained of my father's share. It made life even more difficult because there was no year-end profit to look forward to.

Fernando was sixteen years old when our father died. He had to stop his schooling to help raise the young brood. I was twelve when I started working as a tutor. My mother worked odd jobs everywhere-she sold tomatoes in the public market and I helped her during summers. Josefina worked in a grocery store of a cousin, and later worked as a cashier in a bakeshop. All the other siblings began working when they turned twelve or thirteen to help add to the family income and put themselves through school. 
My eldest sister and my own college tuition were obtained through scholarships from the American Association of College Women. It paid for tuition, with a bit extra to pay for books. I studied at the University of the Philippines during daytime and tutored six children at night. Tutoring was a job I had been doing since I was in grade six when I tutored my landlord's children in exchange for our monthly rent. Our landlord's children were dull and I remember finishing very late every night before I started studying for my own exams. I tried to finish my homework while in school.

The most awful memory I had was when the landlord decided to burn down the entire apartment in exchange for insurance. We were unable to save anything because the fire started from below and our apartment was made of wood. That the landlord was later arrested for arson (because he failed to pay the full amount he promised the arsonist) was no consolation. We lost what meager possessions we had. All our prized certificates of merit were likewise gone. The only consolation was that I didn't have to tutor the landlord's kids anymore and the tutoring job got easier because I started tutoring my cousin's kids and their neighbor's kids and these students were bright.

\section{Influence of College Years}

Among all the siblings, I was the only one to become a social activist. I have always credited my path in life to my experiences at the University of the Philippines:

I was born, grew up and stayed within the confines of parochial Binondo until I got married. I was a product of the bastions of conservatism and ethnocentrism in my elementary and high school days. To say that I suffered "culture shock" in UP was to say it mildly. My freshman year at UP was an exposure to a totally different world. My classmates were more intelligent, more learned, experienced and exposed, and above all, their concerns were more relevant than what I myself had encountered. (See, "UP My Beloved")

It was in college that I started to become aware of my "mis-education." In high school, we were made strongly aware of racial difference. We were educated and prepared for life in the Chinese community and not within mainstream society. On Saturdays, we had to go to school for the weekly "sermons" and stand up for more than an hour listening to someone talk about Chinese civics, about Sun Yatsen, about philosophy, most of which we hardly understood. Love of country was translated as love of China but lamenting that China fell into communist hands and we all had a duty to help bring down the evil communists. We memorized China's provinces, its products, rail system, and rivers. We memorized Chinese history lessons, with hardly any understanding. What I learned of Chinese history I learned in college when I started reading about Asian civilizations. Using Mandarin, 
we memorized lessons in classical Chinese wenyuan wen (文言文) and memorized the translation into baihua wen (白话文). We called literature classes guowen (國 文) and called Chinese language guoyu (國語) without realizing that for us, guoyu should be Filipino. The songs we were taught were patriotic songs about China and anti-communist songs. The stories we read were about Chinese heroes and famous Chinese characters. Later, I would lament that in our English classes, we did not learn much about Filipino national heroes, literature, philosophy, or geography as extensively as we were taught Chinese literature, philosophy, history and geography in our Chinese classes. I would recommend to Filipino educators to emulate the Chinese way of teaching values in school through the stories of nobility, hard work, and sacrifices.

I do not recall any childhood stories about our heroes except for that of Jose Rizal learning to read, throwing his slipper into the river to follow the other one he had lost, and Andres Bonifacio selling paper fans-which are not heroic acts. Contrast this with stories of Chinese heroes who sacrifice for family-that of Hua Mulan, Yue Fei, Kuang Heng. Chinese literature classes were imbued with values and principles. For example, we learned about famous Chinese idioms like "dayu zhishui" (大禹治水, How Brother Yu Tamed the Floods) that taught patience and sacrifice. $)^{10}$

When the older siblings graduated from college, they also helped our mother put the younger ones through college. Putting the siblings through college did not mean full tuition fees since all of them got full or partial scholarships. Financial support for the siblings meant giving allowances for food, books, and transportation fare.

A running joke, which is not really a joke, within the family is that our mother could have been granted multiple university degrees for having assisted many of her children in their thesis research and other assignments. While the children worked, Carmen went the rounds of public libraries in the city and pulled out books for them. She helped them sift through the books because there just was not enough time in the day on top of work and school to slog through all those volumes. These she did on top of full-time work to feed her family. In her later years, she continued supervising or lending a hand even in her grandchildren's studies.

The most remarkable result of all this hard work is that, except for the eldest Fernando, the rest of the ten children are university graduates. And this is all due to our mother's requirement that all siblings help everyone else. This kind of family structure is part of both the Filipino and Chinese culture, but it is emphasized in the Ang family. We have the results before us-a doctor, a teacher, two accountants, four in marketing and business, and two nurses. The youngest brother died young.

The different upbringing brought by the death of the family patriarch differentiated the Ang family from others. We were not business people, we were not rich, but we were very close-knit. To this day, our children marvel at how we rally behind one another, including our nephews and nieces, whenever there is 
a crisis. The problem of one is the problem of all and everyone pulls resources together to help the one in need.

Our family dynamics is quite contrary to the Chinese term "five mourning clothes," meaning close-knit enough to extend across five generations, including the fourth cousins descending from the great-great-grandfather ("Filipino Relatives" 42). Because of my father's early demise, my mother's Filipino upbringing came to the fore and our family's bonds became much more tightly knit.

There was no need to discuss or be conscious about the integration process while we were growing up. We had the support of the Chinese community in terms of scholarships and education, but we also had the support and nurturing from our Filipino mother and some of her relatives.

\section{Integration and citizenship}

Until 1975, the lack of citizenship was the biggest stumbling block to the full integration of the local Chinese into mainstream society. Majority of the local Chinese did not have legal recognition as Filipinos before 1975, even if they were born in the Philippines, grew up, and were educated in the country; therefore, it was understandable that their sense of identification with the Philippines would also suffer.

We were Chinese citizens until we got to elect citizenship when we reached eighteen years old. But we had to spend a lot to elect citizenship because we did not have Alien Certificates of Registration, that is, we did not realize that we should have registered as aliens by virtue of our father being a Chinese citizen. My mother lost her citizenship when she married my father. At the University of the Philippines, I had to pay an additional alien registration fee by virtue of my being a Chinese citizen. My classmates who finished medicine, engineering and other science courses, opted to go abroad right after graduation because they could not take the board examinations anyway. My activist classmates in the Political Science program would always expect me to shell out contributions for our teach-ins, rallies, and other activities, or expect me to fully participate. They thought I was a non-involved bystander because I could not share much. I was self-supporting and I had to help with household expenses, too. Moreover, I could not fully participate in political activities because I was legally an alien. While they could be arrested and jailed, I would be arrested and deported to a country I had never known nor seen. But the activism rubbed off on me and I carried the social consciousness and concern for others long after leaving U.P. The activism deepened my compassion for the Filipino people and heightened my sense of identity as a Chinese Filipino. It was not until 1975 when the citizenship situation changed.

In June 1975, the Philippines established diplomatic relations with the People's Republic of China (PROC). In preparation for this, the Philippines 
had to address two main issues: the question of the allegiance of the local Chinese, and the fear of the Chinese possibly becoming tools of communism. Thus, two presidential decrees (P.D.) specifically addressing these problems were promulgated by then President Ferdinand Marcos before diplomatic relations were established. The first was P.D. 176, promulgated in 1973 to implement the constitutional provision on the Filipinization of all alien schools. The second was Letters of Instruction (LOI) 270 issued on April 11, 1975, just two months before the establishment of diplomatic relations with China. LOI 270 paved the way for the mass naturalization of the resident Chinese by administrative means. ("Race Relations").

\section{The Third Generation}

My husband, Chinben See, was one of the founders of the Pagkakaisa Sa Pagunlad, a non-government organization made up of idealistic and socially-conscious Chinese Filipinos. It was established in 1970 and included, along with Chinben, professionals and academics who advocated the national integration of the ethnic Chinese into mainstream Philippine society. The name of the organization, after all, is Pagkakaisa (Unity) sa Pag-unlad (Progress), a pioneer of the concept of unity in cultural diversity.

My husband's and my quite liberal and forward thinking attitudes toward culture and traditions resulted in a different scenario for my children. Both my husband and I were teachers and cultural workers, and now both children are teachers as well. My husband and I have never adhered to the common practice of going into business and our children grew up knowing their horizons were not limited to anything.

The impetus for the foundation of Pagkakaisa Sa Pag-unlad was the Constitutional Convention slated to open in 1971. The organization aimed to push the jus soli (by birth) form of citizenship among the amendments to the Constitution as the most effective way to achieve integration. The 1935 Constitution adopts the jus sanguinis (by blood) form of citizenship wherein those born of Chinese citizen fathers are considered Chinese citizens even if they were born in the Philippines, grew up, and were educated in the Philippines.

Chinben was among those who were granted Filipino citizenship under the decree. With Filipino citizenship, he could readily teach in Philippine universities-first at De La Salle University and then at the Asian Center of the University of the Philippines. He continued giving lectures and presenting papers on the Chinese in the Philippines at academic conferences locally and abroad.

Many parents of our generation were granted citizenship and hence, during our children's growing-up years, the Chinese-Filipino community evolved into becoming less sinocentric. Acquiring citizenship meant the community was less afraid of becoming milking cows for corrupt government officials. ${ }^{11}$ They began 
moving away from Binondo, and their children, like ours, were brought up without fear.

With both parents being secure about their identities and imparting cultural practices with clear explanations, both our children have navigated being Chinese and Filipino with ease. When my husband died, the eldest was nine and the youngest had just turned one. At the wake, we practiced the burning of incense and let organizations perform three bows to my husband. I explained to my daughter that these were not religious practices and were simply offerings of respect to the dead. My husband and I had talked about it during his illness and we both agreed that we would not observe religious rituals, which were contrary to my and my daughter's own religious practices. Hence, we did not give food offerings nor burned paper money.

It was easier for my daughter to traverse the non-sinocentric environments. She went to a primary school in Quezon City, with classmates who also lived away from Binondo. With this environment, there was less contrast between her and her classmates. They mostly spoke English, Hokkien, Tagalog and code-switched with ease.

My daughter grew up in a Cebuano-Tagalog-Hokkien household. Her father was a Cebuano Tsinoy while I am a Tagalog Tsinoy. Even as a young child, she could code-switch with ease, from Tagalog to English to Hokkien as the situation demanded. I spoke Hokkien with my late husband and that may be where she picked up her Hokkien because I did not teach her to speak Chinese. Our house helpers at home were Cebuano and my daughter and I picked up the language from them and from our yearly visits to my husband's family.

In contrast, when she moved to a Chinatown school for secondary school, Carmelea had to grapple with the sinocentrism among her classmates. Carmelea had always been taught never to use hoan-á (番仔 Hokkien term literally meaning "barbarian") to refer to Filipinos. Upon arrival in the Chinatown-based school, she heard hoan-á left and right, even when there were non-ethnic Chinese classmates in the group.

My daughter recounted that her classmates in secondary school were often confused about their Chineseness or Filipinoness. Often they would say they were Chinese, but could not clearly correlate their identity with their abilities-that they cannot speak Mandarin, nor do they know what their families' ritual traditions mean.

My daughter took up a graduate degree in education and after a few years of teaching at a private university, opted to teach at a public college. My son, who finished Chemistry at the University of the Philippines, opted to teach the course right after graduation and is now at the University of Houston finishing his laboratory coursework for his Ph.D. dissertation. Both chose to be in the academe, I believe, through our influence as their parents. 
My husband's brother prefers that my son go into business, as is the tradition among many Tsinoys. He has met with my son a number of times, trying to convince Sean to establish some sort of business. However, my son told him that while he was not closing the door on business, he prefers to finish his Ph.D. studies because he has only the dissertation left to finish.

In the course of Carmelea's own professional career, she often still encounters misconceptions, especially in more rural towns. When conducting training for public school teachers in the provinces, she is often asked why she is a teacher when she's Chinese. Corollary to that thinking is the assumption that because she is Chinese, then she or her family has a business and is, therefore, rich; because she is rich, then she should not be a teacher.

Another common question is why she can speak fluent Filipino when she is Chinese. It is heartwarming for her to continue educating those she encounters about how she can be both or neither-both Chinese and Filipino, neither in business nor rich.

My early childhood, my growing up years in Binondo, my marriage to an anthropologist-activist, my involvement with Pagkakaisa sa Pag-unlad prepared me to take up the helm of leadership at Kaisa Para Sa Kaunlaran, the successor of the organization my late husband co-founded. The varied experiences, the exposure to different environments, the educational background and the communities I had touched base with were ever-widening circles that shaped my children's and my lives.

Cultural transformation significantly impacts on Chinese-Filipino relations, which in turn either promote or hinder national integration. The issue of cultural transformation has multi-faceted implications on the life of the nation that has an ethnic Chinese minority (Ang See, "Introduction," Intercultural). In the case of the our family, our navigation of the cultural waters promoted our integration into the mainstream Philippine society and the subsequent efforts led toward nation building. 


\section{Notes}

1. As far as her children were informed, the grandfather was a soldier who came with the first batch of American officers who established the American colonial administration after the Treaty of Paris was signed and Spain ceded the Philippines to the United States.

2. Editors' note: "A" (阿) in Hokkien is often used in conjunction with a name, or in this, case, the term used to address a relative. Hence, "a-ko" is the colloquial equivalent of the technical gumu (in pinyin) or ko-bó (in Hokkien).

3. Editors' note: During the Chinese imperial times, children of gentry families were often educated at home in the Confucian classics.

4. Editors' note: This literally means "to know witchcraft."

5. Editors' note: It was common for landlords during the Communist purge to be punished and killed, since they were considered "enemies of the people."

6. Tumbang preso and patintero are Filipino children's games. Tumbang preso needs at least three players, a tin can, and slippers. One player defends the can from being toppled over. The other players throw their slippers at the can and try to topple it. The defender can put the tin can back upright while also running after the other players to tag them. Once tagged, the defender becomes a player. For more detailed rules, refer to "Tumbang preso." Patintero is one of the most widely played games in the country. Six or more players are divided into teams of equal number. One team spreads blockers in a set area, which can be marked on the ground with chalk. All blockers face front or back, with one blocker perpendicular to them. The other team has to pass through the blockers' outstretched arms to get to the other side without being touched. For more detailed rules, refer to "Patintero."

7. Editors' note: As part of Buddhist tradition for venerating the dead, living relatives are required to perform the necessary rituals on these days.

8. My mother converted from Catholicism and joined this church organization when I was about ten years old. This church adheres strictly to the teachings of the Christian Bible and admonishes its members to forego traditional religious rituals and conform only to the teachings of Jesus Christ.

9. Editors' note: This meant either wearing white or black attire for the duration of this time.

10. Hua Mulan disguised herself as a boy to represent her father in response to the emperor's call to arms. Yue Fei's mother tattooed on the young boy's back "avenge the nation" and sent him off to fight the war. Kuang Heng's family could not even afford candles so he bore a hole on his wall to "borrow" the light that seeped through and he could read. Brother Yu spent 12 years living alongside engineers and workers to control the annual flooding from the Yellow River, even foregoing entering his house when he passed by and heard his children crying.

11. In the past, Chinese citizens who had Alien Certificates of Registration could be threatened with deportation if they did not give bribes to the government agent they were dealing with. 


\section{Works Cited}

Barker, Chris, and Dariusz Galasinski. Cultural Studies and Discourse Analysis: A Dialogue on Language and Identity. N.p.: Sage Publications, 2001. Ebook retrieved 30 July 2012 from EBSCO Publishing via Ateneo de Manila University.

Chirot, Daniel. "Conflicting Identities." Essential Outsiders: Chinese and Jews in the Modern Transformation of Southeast Asia and Europe. Eds. Daniel Chirot and Anthony Reid. Seattle: U of Washington P, 1997. 3-32. Print.

Chu, Richard T. Chinese and Chinese Mestizos of Manila: Family, Identity, and Culture 186os-1930s. Leiden: Brill, 2010; Pasig: Anvil, 2012. Print.

"Patintero a.k.a. Tubigan or Harangang." Mga Larong Pilipino. Center for Southeast Asian Studies, Northern Illinois University, n.d. Web. 20 May 2013.

See, Chinben. "Childhood and Hometown." Crossroads: Short Essays on the Chinese Filipinos. Eds. Teresita Ang See and Lily T. Chua. Manila: Kaisa Para Sa Kaunlaran, 1988. 27-9. Print.

--. "Are There More Filipino Relatives?" The Chinese Immigrants: Selected Writings of Professor Chinben See. Ed. Teresita Ang See. Manila: Kaisa Para sa Kaunlaran and Chinese Studies Program, De La Salle University, 1992. 41-3. Print.

See, Teresita Ang. "Citizenship Discussion in the Convention-The Case for Qualified Jus Soli." Philippine-Chinese Profile, Essays and Studies. Ed. Charles J. McCarthy, SJ. Manila: Pagkakaisa Sa Pag-unlad, 1974. 184-211. Print.

---, ed. Intercultural Relations, Cultural Transformation, and Identity, selected papers presented at the 1998 ISSCO Conference. Manila: Kaisa Para sa Kaunlaran, 20oo. Print.

--. "Political Participation, Integration, and Identity of the Chinese Filipinos." The Chinese in the Philippines, Problems and Perspectives, vol. 2. Ed. Teresita Ang See. Manila: Kaisa Para Sa Kaunlaran, 1997. 201-13. Print.

--. "Race Relations, Integration, and Identity Transformation: The Case of the Chinese in the Philippines." Paper delivered at the 19th International Association of Historians of Asia Conference, organized by the Philippine Social Science Council (PSSC), 22-25 Nov. 2006.

--.. "UP My Beloved." Philippine Star, 2 Mar. 2008. Web. 20 May 2013.

Suryadinata, Leo. "Ethnic Chinese and the Nation-State in Southeast Asia." Intercultural Relationships, Cultural Transformation and Identity: the Ethnic Chinese. Selected Papers Presented at the 1998 ISSCO Conference. Ed. Teresita Ang See. Manila: Kaisa Para sa Kaunlaran Inc., 2000. 308-27. Print.

“Tumbang Preso." Tagalog Dictionary, n.d. Web. 20 May 2013. 